Edited by -Francesca Bregoli,

Carlotta Ferrara degli Uberti, Guri Schwarz
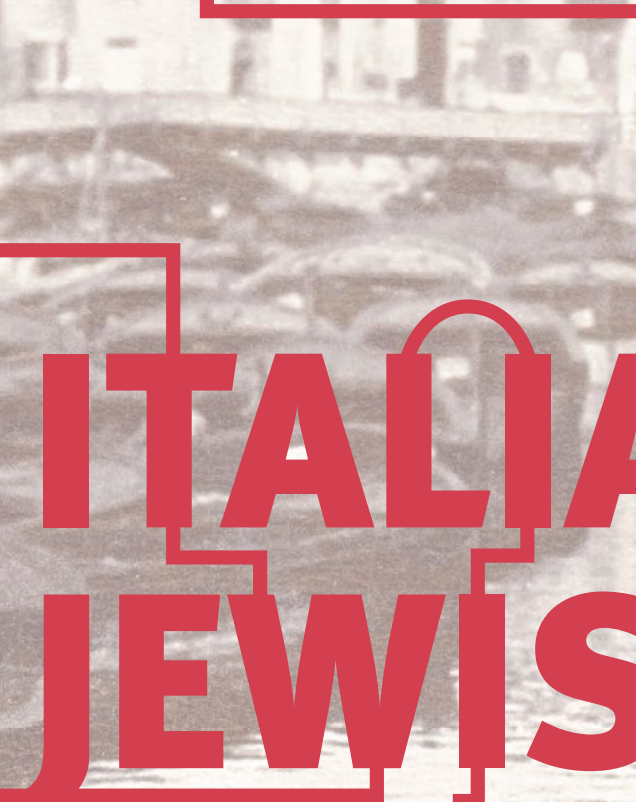


\section{Living in Exile: Wissenschaft des Judentums and the Study of Religion in Italy (1890s-1930s)}

\section{Cristiana Facchini}

Recent scholarship on the Wisseschaft des Judentums has turned its attention to national contexts outside of the German one, where the scientific inquiry of Judaism was deeply rooted. ${ }^{1}$ The Italian case, on which this chapter focuses, is particularly interesting, as it stands both at the center and at the periphery of this intellectual endeavor, and it therefore presents

\footnotetext{
${ }^{1}$ For a general outline see Paul Mendes-Flohr and Jehuda Reinharz, The Jew in the Modern World: A Documentary History, 3rd edition (Oxford: Oxford University Press, 2010); Ismar Schorch, From Text to Context: The Turn to History in Modern Judaism (Hanover, NH: Brandeis University Press, 1994). For a general overview: Kerstin von der Krone and Mirjam Thulin, "Wissenschaft in Context: A Research Essay on Wissenschaft des Judentums," Leo Baeck Institute Yearbook vol. 58 (2013): 249-280. For an interesting study on the United States see Aaron Hughes, The Study of Judaism: Authenticity, Identity, Scholarship (Albany: SUNY Press, 2013).
}

C. Facchini $(\bowtie)$

University of Bologna, Bologna, Italy

e-mail: cristiana.facchini@unibo.it

(C) The Author(s) 2018

F. Bregoli et al. (eds.), Italian Jewish Networks

from the Seventeenth to the Twentieth Century, https://doi.org/10.1007/978-3-319-89405-8_6 
a set of questions that are linked to religion at large, in relation to a society undergoing major cultural and political shifts.

The study of the Wissenschaft des Judentums may be approached through different perspectives: one could focus on scholarly institutions, which were mainly rabbinical theological seminaries, and, less frequently, universities, whose mission was allegedly secular. ${ }^{2}$ Or one could focus on its members, who generally held different opinions on the role of Judaism in contemporary society, spanning from the most pessimistic (such as the opinion attributed to Moritz Steinschneider) to more constructive views, meant to place the study of Judaism at the very core of modern society. ${ }^{3}$

In this chapter, I analyze the Wissenschaft des Judentums in Italy between the 1890s and the 1930s: this period ought to be considered of great interest due to the transnational dimension of the Jewish world at large and the political transformation of Italy from a Liberal regime to Fascism. This period represents, in my reconstruction, the third phase of the Italian Wissenschaft des Judentums. ${ }^{4}$ The first phase, which precedes the formation of the Kingdom of Italy, is characterized by a regional differentiation in terms of religious culture, with references and ties to either France or the German-speaking Habsburg Empire. A second period spanned from the unification of Italy (1860s) to the end of the nineteenth century, a time of strong conflict between the Church and the state. During these years, politics of "secularization" were supported at the establishment level and

${ }^{2}$ There is no extensive research on the European production of knowledge in relation to religions, and Judaism in particular. In some countries the process of "scientification" of religion took place in different institutions, including universities, which were reorganized according to a Humboldtian model. Some general remarks can be found in Giovanni Filoramo, Cos'è la religione (Turin: Einaudi, 2004). The production of knowledge about religion is an interesting lens through which to analyze the development of Wissenschaft des Judentums, and more broadly, the intertwined discourse on religion and Christianity, with which it was often entangled. See also Kocku von Stuckrad, The Scientification of Religion: An Historical Study of Discursive Changes, 1800-2000 (Berlin: De Gruyter, 2014).

${ }^{3}$ For a better evaluation of Steinschneider's work see: Studies on Steinschneider: Moritz Steinschneider and the Emergence of the Science of Judaism in Nineteenth-Century Germany, eds. Reimund Leicht and Gad Freudenthal (Leiden: Brill, 2012).

${ }^{4}$ This chapter is the second installment of a work devoted to Christian and Jews in Italy, Wissenschaft des Judentums and historiography of religion. The first introductory part was presented in Oxford, in 2012. See Cristiana Facchini, "The Making of Wissenschaft des Judentums in a Catholic Country. The Case of Italy," in Wissenschaft des Judentums in Europe: Comparative and Transnational Perspectives, eds. Christian Wiese and Mirjam Thulin (Studia Judaica) (Berlin: De Gruyter, forthcoming). 
discourses about religion in general are very relevant. In Italy, this period is characterized by a strong conflict with the Catholic Church and the marginalization of a political Catholic elite that had previously played an important role in addressing a new understanding of Christian-Jewish relations. ${ }^{5}$ The case of Italy shows great similarities with France, where the Church and a secularizing anti-clerical component of society were in deep conflict at least since the French Revolution. This anti-clerical tradition gave birth, in some countries, to Catholic parties, some of which held also anti-Semitic agendas. ${ }^{6}$ Unlike Germany, where the Kulturkampf launched by Bismarck aimed to attack the conspicuous Catholic minority, France and Italy were characterized by an overwhelming Catholic culture, with its national historical features and a similar anti-Catholic culture. Against this backdrop, Italian Jews were endowed with political rights and a small component of the Italian Jewish elite had the opportunity to enter state institutions and contribute to the formative years of the new kingdom. ${ }^{7}$ During this period, a range of disparate critical discourses on religion developed; many Italian Jewish intellectuals discussed representations and notions of Judaism, just as scholarship and reform of religion went hand in hand in many European countries. ${ }^{8}$ The interpretation of the history of Judaism, and its meaning within this modernizing process, is not irrelevant for European history, and debates between scholars who were part of the Wissenschaft des Judentums and other intellectuals are instructive.

\footnotetext{
${ }^{5}$ For this purpose see David Sorkin, The Religious Enlightenment: Protestants, Jews, and Catholics from London to Vienna (Princeton: Princeton University Press, 2011) and, more specifically, Emanuele D'Antonio, La società udinese e gli ebrei fra la restaurazione e l'età unitaria. Mondi cattolici, emancipazione e integrazione della minoranza ebraica a Udine 1830-1866/1870 (Udine: Pio Paschini, 2012).

${ }^{6}$ There might be some similarities with France, although French Catholics were politically more active in organizing political parties. See Pierre Pierrard, Juifs et catholiques français d'Edouard Drumont à Jacob Kaplan, 1886-1994 (Paris: Cerf, 1997).

${ }^{7}$ For a general overview see Elisabeth Schächter, The Jews of Italy, 1848-1915 (London and Portland, OH: Vallentine Mitchell, 2011); Corrado Vivanti, ed., Storia d'Italia 11. Storia degli ebrei d'Italia. Dall'emancipazione a oggi, vol. 2 (Turin: Einaudi, 1997).

${ }^{8}$ See Cristiana Facchini, David Castelli. Ebraismo e scienze delle religioni tra Otto e Novecento (Brescia: Morcelliana, 2005); Alessandro Guetta, Philosophy and Kabbalah: the Reconciliation of Western Thought and Jewish Esotericism (New York: SUNY Press, 2010 [Italian version 1998]); more recently, Carlotta Ferrara degli Uberti, Making Italian Jews: Family, Gender, Religion and the Nation (London: Palgrave Macmillan, 2017 [Italian version 2011]).
} 
By the end of the nineteenth century the faith in science started to wane, and a third phase began, spanning from the crisis of the fin de siècle to Fascism (1922-1943). ${ }^{9}$ This period is dense in terms of cultural and political events: it witnessed the transformation of the political system from a liberal regime to a totalitarian state, the rise of political Catholicism and the alliance between state and Church, a world war and the deep crisis that grew out of it, and the rise of Zionism. During the first decades of the twentieth century more foreign Jews arrived in Italy. Although Italy was not a hub of immigration, in contrast to other countries, it did indeed attract Jews from elsewhere in small numbers and for various reasons. By the 1930s a small migratory wave had reached the country: some were students who wanted to enroll in the universities which were increasingly barred to them in their native lands, others sought job opportunities, or followed the path created by small groups of exiles who had fled for political reasons. ${ }^{10}$ The period that comprises the end of the Liberal age and the rise and consolidation of Fascism is of great interest for the study of religion: scholars of various religious backgrounds encountered one another, and as a result their research was influenced by numerous and diverse currents of European thought. However, their lives encountered innumerable obstacles, often of a political nature with the rise of Fascism. The implementation of the racial laws was, indeed, a tragic development in the lives and works of Jewish scholars and students, some of whom reached Italy because of Mussolini's promise that the country was devoid of anti-Semitism. ${ }^{11}$

One of the master narratives of Jewish historiography when it comes to the Italian Wissenschaft starts with the arrival to Italy of a small group of "Polish" (Galician) rabbis, who were mostly educated at the Rabbinical Theological Seminary of Breslau and in German universities. Like many

\footnotetext{
${ }^{9}$ Facchini, "The Making of Wissenschaft des Judentums."

${ }^{10}$ For some information about Russian émigrés see: Asher Salah, "From Odessa to Florence: Elena Comparetti Raffalovich. A Jewish Russian Woman in Nineteenth-Century Italy," in Portrait of Italian Jewish Life (1800s-1930s), eds. Tullia Catalan and Cristiana Facchini, Quest. Issues in Contemporary Jewish History. Journal of Fondazione CDEC, n.8 November 2015; an interesting insight in Clara Sereni, Il gioco dei regni (Florence: Giunti, 1993).

${ }^{11}$ Ludwig's interview appeared in 1932. Meir Michaelis, Mussolini and the Jews: GermanItalian Relations and the Jewish Question in Italy, 1922-1945 (Oxford: Oxford University Press, 1978); Renzo De Felice, Storia degli ebrei italiani sotto il fascismo (Turin: Einaudi, 1961); Michele Sarfatti, Gli ebrei nell'Italia fascista. Vicende, identità, persecuzione (Turin: Einaudi, 2000) and idem, The Jews in Mussolini's Italy: From Equality to Persecution, trans. by John and Anne C. Tedeschi (Madison: Wisconsin University Press, 2006).
} 
other rabbis who engaged with scholarship on Judaism, they acted both as members of the Italian Jewish community with its local rationale, and as scholars of Judaism operating within the greater network of the Wissenschaft des Judentums and European scholarship on religion. As we shall see, in their capacity as rabbis, they were also exposed to the political whims of the Fascist regime, being simultaneously fully integrated into its fabric. ${ }^{12}$

I will interpret their works alongside the production of a younger generation of Italian Jews, who were born around the 1870s or 1880s and whose stories are parallel to the ones of the "Polish rabbis." This Italian generation of scholars was influenced by a culture that had been, as I said, characterized by the conflict with the Catholic Church, and by the establishment of Positivism. Many among them felt obliged to rebel against the tradition of Positivism: they shared similar paths of cultural education, and were especially imbued with the ethos of neo-Idealism, whose main tenets were elaborated by the Italian philosopher and historian Benedetto Croce and the powerful academic and then Fascist Minister of Culture, Giovanni Gentile. ${ }^{13}$

In doing so, I will focus on themes that were both relevant for the Wissenschaft des Judentums and for scholarship on religious issues, especially the ones related to the history of Judaism, its relationship with the rise of Christianity, and the research on the historical Jesus.

\section{Wandering Scholars: The Arrival of the Polish Rabbis}

By the beginning of the twentieth century the study of religion had become a well-established academic discipline or an important topic of research among psychologists and sociologists, being significant for philosophers

\footnotetext{
${ }^{12}$ The foundation of Jewish theological seminaries was a widespread European and then American phenomenon. They were modeled after the Protestant and, sometimes, Catholic theological seminaries, and mainly meant to form an educated and modern religious leadership. For Breslau see Das jüdisch-theologische Seminar (Fränckelsche Stiftung) zu Breslau, am Tage seines fünfundzwanzigjührigen Bestehens, den 10. August 1879 (Breslau, 1879); Zur Geschichte des Jüdisch-Theologischen Seminars, in Programm zur Eröffnung des JüdischTheologischen Seminars (Breslau, 1854).

${ }^{13}$ Gennaro Sasso, Benedetto Croce. La ricerca della dialettica (Naples: Morano, 1975); Guido Verucci, Idealisti all'Indice. Croce, Gentile e la condanna del Sant'Uffizio (Rome-Bari: Laterza, 2006); Girolamo Cotroneo, Croce filosofo italiano (Florence: Le Lettere, 2015); Gabriele Turi, Giovanni Gentile. Una biografia (Florence: Giunti Editore, 1995); Alessandra Tarquini, Il Gentile dei fascisti: gentiliani e antigentiliani nel regime fascista (Bologna: Il Mulino, 2009).
} 
and theologians as well. ${ }^{14}$ This new current had a relevant impact on the Wissenschaft des Judentums as well. The renowned scholar of Jewish mysticism, Gershom Scholem, began his groundbreaking career in those years, when new interpretations of mythology and ritual were both elaborated and influenced by the rise of psychology, such as Karl Jung's discovery of archaic patterns of religious behavior. ${ }^{15}$ Further, the American psychologist William James had published his landmark Gifford Lectures under the title Varieties of Religious Experience, a book that reached a wide international public and was to be translated into Italian. ${ }^{16}$

By the early twentieth century and continuing in the following decades, a sort of nostalgia for the past began to be conceptualized by historians of religions and members of the Wissenschaft des Judentums. ${ }^{17}$ Philological precision and high textual specialization were accompanied by the desire to redescribe and reassess the Jewish past, as the cases of Gershom Scholem or Martin Buber indicate.

The case of Solomon Schechter is useful in order to better grasp the atmosphere of the time, embodied by some of the scholars whose work we will describe below. Schechter (1847-1915) was born in Moldavia, the son of a ritual butcher living in a community of Hasidim. He was educated within the framework of a traditional community, from cheder to yeshiva, but then moved to Vienna, where he earned a rabbinical degree at the

\footnotetext{
${ }^{14}$ For a broader picture see Hans Kippenberg, Die Entdeckung der Religionsgeschichte. Religionswissenschaft und Moderne (München: C.H. Beck, 1997). There are a number of specific contributions based on national historiography.

${ }^{15}$ On Scholem's intellectual contribution to the study of religion see Steven Wasserstrom, Religion after Religion: Gershom Scholem, Mircea Eliade and Henri Corbin at Eranos (Princeton: Princeton University Press, 1999); David Biale, Gershom Scholem: Kabbalah and Counter-History (Cambridge, MA: Harvard University Press, 1982); Harold Bloom, ed., Gershom Scholem (New York: Chelsea Books, 1987); Joseph Dan, Gershom Scholem and the Mystical Dimension of Jewish History (New York: New York University Press, 1988); Paul Mendes-Flohr, ed., Gershom Scholem: The Man and his Work (New York and Jerusalem: SUNY Press, 1994); Amir Engel, Gershom Scholem: an Intellectual Biography (Chicago and London: University of Chicago Press, 2017). On psychology and religion see the comparison between Jung and Freud in Michael Palmer, Freud and Jung on Religion (London and New York: Routledge, 2003).

${ }^{16}$ William James, The Varieties of Religious Experience: A Study in Human Nature (New York: Longmans Green \& Co., 1902).

${ }^{17}$ See Cristiana Facchini, "Narrating, Visualizing, Performing, and Feeling a Religion. On Representations of Judaism," in Dynamics of Religion: Past and Present, eds. Christoph Bochinger and Jörg Rüpke (together with Elisabeth Begemann), Religionsgeschichtliche Versuche und Vorarbeiten 67 (Berlin: De Gruyter, 2016), 273-296.
} 
Jewish Theological Seminary. By the end of the nineteenth century Schechter had moved to England where he was appointed lecturer in Talmudics and reader of Rabbinics at the University of Cambridge. One may note that Schechter's appointment was rather exceptional for those years, especially in regard to the academic study of post-biblical literature. From there Schechter became involved with the extraordinary discovery of the Cairo Genizah, whose whereabouts were located by two Christian missionary women in Egypt around 1896. ${ }^{18}$ Following his emigration to the United States, Schechter proved to be influential in directing the lines of research on Judaism, as well as in the organization of the Rabbinical Theological Seminary in New York. ${ }^{19}$ His example is indicative of the level of transnational scholarship and the mobility of scholars that was such a defining mark of intellectual life of the time.

One of the key figures among the "Polish rabbis" was Samuel Hirsch Margulies (1858-1922), a warm, passionate Orthodox Jew and a committed Zionist since the movement's beginnings. Margulies was born and raised in the Polish-Ukrainian city of Berezhany, which was then part of the Habsburg Empire. He earned a rabbinical degree at the Jewish Theological Seminary of Breslau, and was educated in the universities of Breslau and Leipzig, where he studied Oriental languages. Margulies arrived at the end of the nineteenth century in Florence, and in 1890 he was appointed chief rabbi in Florence, where he taught at the Collegio rabbinico, relocated from Padua and revived in 1889, becoming its director in 1899. ${ }^{20}$ In Florence, he also established two new Jewish periodicals, the

\footnotetext{
${ }^{18}$ Adina Hoffman and Peter Cole, Sacred Trash: The Lost and Found World of the Cairo Geniza (New York: Schocken, 2011); Amitav Ghosh, In an Antique Land (New York: Vintage Books, 1992); Janet Soskice, The Sisters of Sinai: How Two Lady Adventurers Discopered the Hidden Gospels (New York: Vintage Books, 2009).

${ }^{19}$ Cyrus Adler, Solomon Schechter: A Biographical Sketch (Philadelphia: The American Jewish Yearbook, 5677/1916). Schechter developed the notion of "Catholic Israel." See Solomon Schechter, Studies in Judaism, 3 vols. (London: A. \& C. Black, 1896-1924). On the Conservative movement in Judaism: Michael R. Cohen, The Birth of Conservative Judaism: Solomon Schechter's Disciples and the Creation of an American Religious Movement (New York: Columbia University Press, 2012); Massimo Giuliani, "Gli Ebrei Conservative negli Stati Uniti e il Jewish Theological Seminary," in Le religioni e il mondo moderno, ed. by David Bidussa, Ebraismo, vol. 2 (Turin: Einaudi, 2008), 385-405.

${ }^{20}$ Lionella Viterbo, "La nomina del rabbino Margulies: Un 'excursus' nella Firenze ebraica di fine Ottocento,” La Rassegna Mensile di Israel 3, 59 (1993): 67-89.
} 
Settimana israelitica and the Rivista israelitica. ${ }^{21}$ Margulies was a charismatic rabbi, and went on to exert immense influence over the Italian Jewish community, especially through his cultural, political, and scholarly endeavors. ${ }^{22}$ His intellectual activity was multifaceted: as a rabbi and religious leader, he worked relentlessly as a preacher, teacher, and organizer. His publications are quite telling in that sense; his commitment to Zionism instilled Orthodox Jews with religious nationalism and an activism toward Jewish solidarity. ${ }^{23}$

Margulies-an expert on medieval Jewish biblical exegesis-published his scholarly works in German. His most quoted work was dedicated to Saadya Gaon. Interestingly, in 1896 Margulies wrote a short biography of one of the most important Italian Jews of the time, David Levi (1816-1898). ${ }^{24}$ In his portrait, Margulies translated some of Levi's poems into German, and specifically those that were most imbued with the

${ }^{21}$ Attilio Milano, "Un secolo di stampa ebraica in Italia. Scritti in onore di Dante Lattes," Rassegna Mensile di Israel XII (1938): 96-136; Ferrara degli Uberti, Making Italian Jews, 24.

${ }^{22}$ Elio Toaff, "La rinascita spirituale degli ebrei italiani nei primi decenni del secolo," La Rassegna Mensile di Israel, nn. 7-12, XLVII (1981): 63-73; Simonetta Della Seta Torrefranca, "Identità religiosa e identità nazionale nell'ebraismo italiano del Novecento," in Italia Judaica. Gli ebrei nell'Italia unita, 1870-1945, Atti del IV convegno internazionale, Siena 12-16 giugno 1989 (Rome: Ministero per i beni culturali e ambientali, 1993), 263-272.

${ }^{23}$ Lionella Viterbo, Spigolando nell'archivio della comunità ebraica di Firenze (Florence: Giuntina, 1997); Sara Airoldi, "Practices of Cultural Nationalism. Alfonso Pacifici and the Jewish Renaissance in Italy (1910-1916)," in Portrait of Italian Jewish Life (1800s-1930s), eds. Catalan and Facchini, Quest. Issues in Contemporary Jewish History. Journal of Fondazione CDEC, n.8 November 2015 (www.quest-cdecjournal.it/focus.php?id=367); on Italian Zionism see Alberto Cavaglion, "Tendenze nazionali e albori sionistici," in Storia d'Italia. Annali XI: Gli Ebrei in Italia, ed. Corrado Vivanti, vol. 2 (Turin: Einaudi, 1997), 1291-1320; Simonetta Della Seta, Daniel Carpi, "Il movimento sionistico," in Storia d'Italia. Annali XI: Gli Ebrei in Italia, vol. 2, 1321-1368; Ferrara degli Uberti, Making Italian Jews, 182-195; Arturo Marzano, Una terra per rinascere. Gli ebrei italiani e l'emigrazione in Palestina prima della guerra (1920-1940) (Genoa-Milan: Marietti, 2003). For a general approach Michael Berkowitz, Zionist Culture and West European Jewry before the First World War (Chapel Hill: North Carolina University Press, 2003); Georges Bensoussan, Une histoire intellectuelle et politique du sionisme (Paris: Fayard, 2001).

${ }^{24}$ Samuel H. Margulies, Saadja Alfajûmi's arabische Psalmen-Üebersetzung (Breslau, 1884); idem, Discorsi sacri (Florence: Galletti e Cassuto, 1905); idem, Dichter und Patriot: Eine Studie neber das Leben und die Werke D. Levis (Trier: Sigmund Mayer, 1896); idem, Discorsi e scritti varii (Florence: Israel, 1923). On David Levi see Francesca Sofia, "Gli ebrei risorgimentali fra tradizione biblica, libera muratoria e nazione," in Storia d'Italia: La massoneria (Annali 21), ed. Gian Mario Cazzaniga (Turin: Einaudi, 2006), 244-265. 
Risorgimento's pathos. This homage to Levi can also be seen as an early acknowledgment of Jewish patriotism that would somehow connect with late nineteenth century Zionism. ${ }^{25}$

Although Margulies influenced a generation of rabbis and Italian young Jews, who became devoted Zionists, he nevertheless invited a few Germaneducated younger colleagues to teach at the Collegio rabbinico, including the outstanding scholar Ismar Elbogen (1874-1943), who taught biblical Hebrew and Jewish history from 1889 to $1902,{ }^{26}$ and Hirsch Perez Chajes (1876-1927), who published his main works in German and collaborated with the University of Florence. ${ }^{27}$

Their appointment at the Collegio rabbinico did not go unchallenged. Criticism was voiced, mainly in Jewish periodicals. It was argued that the German rabbis were too scholarly or too cold, but the main issue was that they were foreigners. ${ }^{28}$ Elbogen, who was not a committed Zionist, moved to Berlin shortly afterwards, where he was appointed at the Hochschule für die Wissenschaft des Judentums. ${ }^{29}$ His experience in Italy had not been pleasant, although he paid tribute to the Italian Wissenschaft des Judentums with articles devoted to one of its outstanding representative, Samuel David Luzzatto; it is also likely that he maintained collaborative relationships with some of his Italian-Galician colleagues. ${ }^{30}$ Elbogen should be remembered not only for his groundbreaking work on Jewish liturgy, but also as a vocal critic of both Harnack and Bousset, the outstanding scholars of early Christianity and ancient religious history. ${ }^{31}$

Chajes was also from Galicia, the offspring of an important member of the Polish Haskalah. In contrast to Margulies and Elbogen, Chajes studied at the rabbinical theological seminary of Vienna where he was ordained in

\footnotetext{
${ }^{25}$ See Leo Neppi Modona, "17 lettere di S. H. Margulies a David Levi," La Rassegna Mensile di Israel 28 no. 2 (1962): 62-75.

${ }^{26}$ Among his works, see Ismar Elbogen, Der jüdische Gottesdienst in seiner geschichtlichen Entwicklung (Leipzig, 1913); idem, Die neueste Construction der jüdischen Geschichte (Breslau, 1902); idem, In commemorazione di S. D. Luzzatto (Florence, 1901). Christian Wiese, Challenging Colonial Discourse: Jewish Studies and Protestant Theology in Wilhelmine Germany (Leiden: Brill, 2004).

${ }^{27}$ Salo W. Baron, "Hirsch, Peretz Chajes," Encyclopaedia Judaica vol. 5 (1971-1972): $325-326$.

${ }^{28}$ Alberto Latorre, Il carteggio Zolli-Pettazzoni (1925-1956) (Brescia: Morcelliana, 2015).

${ }^{29}$ Wiese, Challenging Colonial Discourse.

${ }^{30}$ Latorre, Il carteggio Zolli-Pettazzoni.

${ }^{31}$ See, for example, his book on the Pharisees; Wiese, Challenging Colonial Discourse.
} 
1899. He arrived in Italy when he was in his twenties. He taught at the Collegio rabbinico in Florence from approximately 1902 to 1912, and in 1904 he became adjunct professor at the renowned Istituto di Studi Superiori (University of Florence), where David Castelli had held the chair of biblical Hebrew before him. ${ }^{32}$ He later became Chief Rabbi of Trieste, where he spent a few years (1912-1916) until he returned to Vienna, where he performed his duties of Chief Rabbi until his death in 1927. Chajes was both a scholar and an important religious and political leader, as most of the research on Austrian Jews indicates. In Vienna he became acquainted with Salo W. Baron, the future American historian of Jewish history, who was also from Galicia. ${ }^{33}$ Chajes' works addressed, among other things, the scholarly study of the New Testament, as reflected in his book on the Gospel of Mark. ${ }^{34}$ I shall return to this topic, which was a significant one to Jews of the early twentieth century. Chajes was destined to become one of the most important religious leaders of the Habsburg Empire, as, following World War I, he was increasingly seen as one of the most vocal supporters of Jewish refugees, both in Vienna and Trieste. For the purposes of this essay it will suffice to observe that, as Salo Baron suggested, most of Chajes' scholarly works were produced during his stay in Florence, where among other things, he influenced the younger Umberto Cassuto and Israel Zoller. ${ }^{35}$

Israel Zoller (1881-1956) was another Jewish scholar who had come from Polish Galicia. Unlike his older colleagues, Zoller was educated in Italy, both at the Collegio rabbinico and the University of Florence, where he met Elbogen and Chajes. The biography of Zoller is probably the most complicated one, given the dramatic turn it took after his decision, in

${ }^{32}$ Cristiana Facchini, David Castelli.

${ }^{33}$ See Umberto Cassuto, "Hirsch Perez Chajes," La Rassegna Mensile di Israel 3 no. 5 (1928): 218-232; Elias S. Artom, Umberto Cassuto and Israel Zoller, Miscellanea di studi ebraici in memoria di H. P. Chajes (Florence, 1930); Salo W. Baron, "Hirsch Perez Chajes," Encyclopaedia Judaica, vol. 5, Jerusalem 1971/72, 325-326; On Chajes see David N. Myers, "Was there a 'Jerusalem School'? An Inquiry into the First Generation of Historical Researchers at the Hebrew University" (http://www.sscnet.ucla.edu/history/myers/ Was\%20there\%20a\%20Jerusalem\%20School.pdf).

${ }^{34}$ Baron, "Hirsch Peretz Chajes"; some references also in Shmuel Almog, Jehuda Reinharz and Anita Shapira, eds., Zionism and Religion (Hanover and London: Brandeis University Press, 1998), $154 \mathrm{ff}$.

${ }^{35}$ Baron, "Hirsch Peretz Chajes." 
1944, to convert to Catholicism. ${ }^{36}$ Zoller's dual identity is especially interesting because it did not only involve his role as both a religious leader and a scholar, but also his shift from religious Judaism to Catholicism. Above all, Zoller was a gifted scholar who dealt with a wide array of topics, as was customary at the time. Also, similarly to many of his colleagues, he published in scholarly journals, both in German and Italian. Zoller was interested in psychoanalysis and anthropology, whose theories he tried to apply to his interpretation of the Bible, in collaboration with scholars of religions. ${ }^{37}$ These interests fueled outrage among his coreligionists in Trieste, but his writings nevertheless timidly circulated. In contrast to his other colleagues, Zoller's entire career took place in Italy, where he remained even after his conversion. Zoller's writings were far-reaching in their breadth, although his conversion to Catholicism contributed to his final marginalization: he continued teaching and writing on Judaism and Christianity, but now protected by the walls of Vatican City.

The youngest of the Galician Jews who relocated to Italy and performed rabbinical functions was Isaiah Sonne (1887-1960), who was born in Moscisko (Galicia, Hapsburg Empire), and educated in Switzerland and Italy, where he received his rabbinical degree in $1925 .{ }^{38}$ After a short period in Lodz, he returned to Italy and taught Talmud and Rabbinical Literature at the Collegio rabbinico of Florence. From 1936 to 1938 Sonne served as director of the Rabbinical Theological Seminary of Rhodes, Greece, which had become part of Italy in 1912, during the first phase of

\footnotetext{
${ }^{36}$ Robert G. Weisbord and Wallace P. Sillanpoa, The Chief Rabbi, the Pope, and the Holocaust: An Era in Vatican-Jewish Relations (New Brunswick: Transaction Publishers, 2008); Gabriele Rigano, Il "caso Zolli": L'itinerario di un intellettuale in bilico tra fedi, culture e nazioni (Milan: Guerini e Associati, 2006). It is difficult to fully grasp the reasons that drove Zoller to conversion. He himself later constructed a self-explanation typical of conversion narratives. For relevant insight on this topic see John Connelly, From Enemy to Brother: the Revolution in Catholic Teaching on the Jews, 1933-1965 (Cambridge, MA and London: Harvard University Press, 2012); Todd Endelman, Leaving the Jewish Fold: Conversion and Radical Assimilation in Modern Jewish History (Princeton: Princeton University Press, 2015).

${ }^{37}$ On this, see his correspondence with Raffaele Pettazzoni, the dean of the history of religions in Italy: Alberto Latorre, "La storia delle religioni tra 'ragioni di prudenza' e 'ragion di stato': Uno spaccato della ricerca storico-religiosa al tempo del fascismo e della reazione anti-modernista nella corrispondenza di Israel Zoller con Raffaele Pettazzoni," Studi e materiali di storia delle religioni 77 no. 1 (2011): 65-85; idem, Il carteggio Zolli-Pettazzoni.

${ }^{38}$ There is a brief discussion of Sonne in Salo W. Baron, "Isaiah Sonne, 1887-1960," Jewish Social Studies 23 no. 2 (April 1961): 130-132.
} 
Italian colonial expansion. ${ }^{39}$ After the implementation of the anti-Semitic laws in 1938, Sonne was forced to flee the country and moved to the United States, where he ultimately worked and taught at the Hebrew Union College of Cincinnati. ${ }^{40}$

Sonne's contribution to the Wissenschaft des Judentums was considerable, especially in the field of Renaissance history. He published extensively in Italian, Hebrew, German, and English on a broad range of topics, from bibliography to history, and from rabbinics to philosophy. ${ }^{41} \mathrm{His}$ rabbinical work in Rhodes should also be analyzed within the context of the establishment of Jewish agencies, such as the Alliance Israélite Universelle, which since the nineteenth century had been cooperating with the local government to modernize and educate Jews from North Africa, the Middle East, and Southern Europe..$^{42}$ Moreover, these agencies are also to be understood against the backdrop of colonial policies enacted by many European states since 1878. Salo Baron stressed this feature of Sonne's activity in Rhodes:

[Sonne] served as a director of the Jewish Theological Seminary on the island of Rhodes whose main function, from the standpoint of the Italian government which subsidized it, was to help spread Italian culture in the Middle East with the cooperation of its alumni serving in various rabbinic posts in the area. To Sonne, however, its great mission consisted in infusing Levantine Jewry with the spirit of the Wissenschaft des Judentums and thus helping to bridge the gaps between the intellectual developments in the Western and Eastern Jewries. ${ }^{43}$

${ }^{39}$ On the relationship between Jews and the Italian colonial experience see Renzo De Felice, Ebrei in un paese arabo. Gli ebrei nella Libia contemporanea tra colonialismo, nazionalismo arabo e sionismo (Milan: Giuffrè, 1982); some information in Martino Contu, Nicola Melis, Giovannino Pinna, eds., Ebraismo e rapporti con le culture del Mediterraneo nei secoli XVIII-XX (Florence: Giuntina, 2003).

${ }^{40}$ Michael A. Meyer, Judaism within Modernity: Essays on Jewish History and Religion (Detroit: Wayne State University Press, 2001), 345-361.

${ }^{41}$ Abraham S. Halkin, "Isaiah Sonne (1887-1960), the Historian," Proceedings of the American Academy for Jewish Research 29 (1960-1961): 9-15.

${ }^{42}$ For South Europe see: Tullia Catalan and Marco Dogo, eds., The Jews and the NationStates of Southeastern Europe from the 19th Century to the Great Depression: Combining Viewpoints on a Controversial Story (Newcastle: Cambridge Scholars, 2016); Aron Rodrigue, French Jews, Turkish Jews: The Alliance Israélite Universelle and the Politics of Jewish Schooling in Turkey, 1860-1925 (Bloomington: Indiana University Press, 1990).

${ }^{43}$ Baron, "Isaiah Sonne 1887-1960." 
The case of Sonne brings out two significant issues. The first concerns the Jewish support of the Fascist regime, which is most evident among those who held important institutional roles. The second concerns the scholarship on religion and Judaism in its transnational and Fascist contexts, its legacy, and the relationship with other traditions, Catholic and secular alike.

\section{2 “A Jew Among the (Catholic) Modernists": A Religious Turn?}

My family had been detached from Jewish religious practice for two generations, on my father's side even for three, since at the beginning of the nineteenth century my father's maternal grandparents had welcomed the anti-confessional and humanitarian principles of the Enlightenment, and those had been transmitted in their entirety to my father, quite modernized by the political and economic Liberalism typical of the Historical Right. [...] And thus, between the end of the gymnasium and the beginning of the lyceum, I started to teach myself some Hebrew and immersed myself in the Old and New Testament. I avidly searched for any sort of books about religion and history of religions, relying above all on those that I found in the family library, collected mostly by a great-great-grandfather and a greatuncle of mine, which faithfully reflected the development [of religious themes] from eighteenth-century Enlightenment toward nineteenth-century Positivism, passing through the experience of Romanticism-three phases meaningfully marked by three "lives of Jesus," which I found in our library and which I devoured: those by Baron D'Holbach, David Friedrich Strauss, and Ernest Renan. ${ }^{44}$

${ }^{44}$ Giorgio Levi Della Vida, Fantasmi ritrovati (Naples: Liguori, 2004), 59-60: "Da due generazioni la mia famiglia era staccata dalla pratica della religione ebraica, nella linea paterna addirittura da tre, poiché tra i nonni materni di mio padre ai primi dell'Ottocento avevano accolto i principii anticonfessionali e umanitari del secolo dei lumi, e questi si erano trasmessi integralmente a mio padre, ammodernati alquanto dal liberalismo politico ed economico della destra storica. [...] Fu così che, tra la fine del ginnasio e il principio del liceo, cominciai a studiare da me un po' di ebraico, a immergermi nella lettura dell'Antico e del Nuovo Testamento, a dare la caccia a ogni sorta di libri che trattassero di religione e di storia delle religioni, valendomi sopra tutto di quelli che trovavo in casa, raccolti per la più gran parte da un mio trisavolo e da un mio prozio e nei quali si rispecchiava con fedeltà lo sviluppo dell'illuminismo settecentesco verso il positivismo ottocentesco attraverso l'esperienza del romanticismo: tre tappe segnate da tre vite di Gesù che trovai nella biblioteca domestica e mi affrettai a leggere avidamente: quelle del barone d'Holbach, di David Friedrich Strauss, di Ernest Renan." The title of the lengthy chapter is "Un ebreo tra i modernisti" (A Jew among 
Written in the 1960s, this long autobiographical excerpt conveys a glimpse of Giorgio Levi Della Vida's youth, when he decided to become a scholar of Oriental Studies. It is a well-known and oft-quoted passage, part of a chapter that he wrote in memory of the "Catholic modernists," and may be used as a perfect example to show the multiple relations between Jews and Christians in this environment. Giorgio Levi Della Vida (1886-1967) was born in Venice, into a bourgeois Jewish family. He studied in Rome with Ignazio Guidi, an important scholar of the previous generation. Della Vida became a renowned scholar; his work and career belong to the history of European Orientalists, many of whom were Jews. ${ }^{45}$ In Rome he eventually met Baron Leone Caetani, a great scholar of Arabic literature, who left Italy after the rise of Fascism. ${ }^{46}$

Levi Della Vida taught Hebrew at the University of Rome from 1919 until his resignation in 1931, when he refused to swear the loyalty oath to Fascism. In 1938, he fled the country, along with many other Italian Jewish scholars who eventually found refuge in South America, the United States, and England. ${ }^{47}$

the Modernists), which refers mainly to his friends many of whom were Catholics or scholars of Christianity, like for example Luigi Salvatorelli, to whom the book was dedicated. The first edition was published in 1966, a year before his death.

${ }^{45}$ On Jews as orientalists see Ivan D. Kalman and Derek Penslar, eds., Orientalism and the Jews (Waltham: Brandeis University Press, 2005); Italian orientalism has not yet been critically analyzed. The case of Levi Della Vida is very relevant within the context of scholarship on Islam in Europe, also as a "Jewish" scholar. Levi Della Vida was himself very critical of Said's interpretation of "Orientalism." See Cristiana Facchini, "Orientalistica ed ebraismo: Una storia ai margini. David Castelli e Giorgio Levi Della Vida," in La storiografia storicoreligiosa italiana tra la fine dell'800 e la seconda guerra mondiale, eds. Mario Mazza and Natale Spineto (Alessandria: Edizioni dell'Orso, 2014), 111-139.

${ }^{46}$ Bruna Soravia, Giorgio Levi Della Vida, Dizionario biografico degli italiani 64 (2005), http://www.treccani.it/enciclopedia/levi-della-vida-giorgio_(Dizionario-Biografico); Levi Della Vida, Fantasmi ritrovati.

${ }^{47}$ Ignazio Guidi (1844-1935) was one of the most important Italian orientalists of his time. His scholarly production was extensive and highly specialized, although it can be divided into three main areas: literature of the Oriental Churches, History and literature of Ethiopic, Arabic-Islamic literature. He also worked as a translator of juridical texts from Libya and was, along with many of his contemporaries, a strong supporter of the Italian colonial enterprise. See Bruna Soravia, Ignazio Guidi, Dizionario biografico degli italiani, 61 (2004): http:// www.treccani.it/enciclopedia/ignazio-guidi_res-6635a523-87ee-11 dc-8e9d0016357eee51_(Dizionario-Biografico)/ and eadem, "Ascesa e declino dell'orientalismo scientifico in Italia," in Il mondo visto dall'Italia, eds. Agostino Giovagnoli and Giorgio Del Zanna (Milan: Guerini: 2005), 271-286. His influential article-Ignazio Guidi, "Della sede primitiva dei popoli semiti," in Memorie dell'Accademia nazionale dei Lincei, cl. di scienze 
It is not inappropriate to introduce this chapter with a reference to "Catholic modernism," as Levi Della Vida did in his autobiography. This reference to the modernist priests indicates a growing interest in the study of religion, despite the Catholic Church's official criticism of it and its growing attempt to keep it under control. Besides Levi Della Vida's contact with modernist priests, the autobiographical excerpt reveals two important features of his constructed self-narrative: the first recounts his "discovery of religion," after his family had been estranged for "at least three generations." Levi Della Vida's decision to become an Orientalist seems to have been determined by his interests in religion. The second interesting reference is linked to books that inspired him, namely Renan's La vie de Jésus and David Strauss' Das Leben Jesu (Life of Jesus), both bestsellers of the nineteenth century. ${ }^{48}$

Levi Della Vida's academic activities encompass more than a scholarly body of work devoted to religion and Oriental culture; they speak of the intellectual, religious, and political life of Italy in those years, of his relentless opposition to Fascism, of his life in isolation inside Italy when working for the Vatican after 1931, and then his exile to the United States, after 1938. ${ }^{49}$ As an Orientalist, Levi Della Vida wrote several important articles about the history of ancient Israel, some of which were to be published in the Enciclopedia italiana, edited by Giovanni Gentile. ${ }^{50}$ His contribution to the interpretation of ancient Judaism and Islam as religions is of great importance.$^{51}$ On more than one occasion, Levi Della Vida expressed his own ideas about the role and character of Christianity, although he abstained from a thorough investigation into that field of research.

morali, storiche e filologiche, s. 3, IV [1879], 566-615-was discussed by Levi Della Vida in 1938 in his lectures at the Collège de France. See Facchini, "Orientalistica ed ebraismo: Una storia ai margini."

${ }^{48}$ For a cultural approach to the study of the historical Jesus see Halvor Moxnes, Jesus and the Rise of Nationalism: A New Quest for the Nineteenth Century (London and New York: I.B. Tauris, 2012); on Renan: Robert Priest, The Gospel according to Renan: Reading, Writing, and Religion in Nineteenth-Century France (Oxford: Oxford University Press, 2015 ).

49 "Dual exile" is a term I borrow from Arnaldo Momigliano's review of Giorgio Levi Della Vida, Fantasmi ritrovati (Venice: Neri Pozza, 1966), in Quarto contributo alla storia degli studi classici e del mondo antico (Rome: Ed. Storia e Letteratura, 1969), 663-665; published previously in Rivista storica italiana 78 (1966): 740-442.

${ }^{50}$ Gabriele Turi, Il mecenate, il filosofo e il gesuita. L' "Enciclopedia italiana", specchio della nazione (Bologna: Il Mulino, 2002).

${ }^{51}$ His depiction of Islam is quite interesting as it runs against much of Said's claims in his Orientalism (1978). 
The position which Levi Della Vida vacated in 1931 was given to rabbi Umberto Cassuto (1883-1951). Cassuto graduated from the University of Florence in 1906 and was ordained in the same city in $1908 . .^{52}$ After serving as a rabbi, he taught for some time at the University of Florence and then moved to Rome. Cassuto was both a biblical scholar and a historian. In 1913 he published a masterpiece on the Jews of Florence during the Renaissance, which was awarded a prize by the Accademia dei Lincei in $1920 .^{53}$ Cassuto was also a daring biblical scholar who criticized the "documentary hypothesis," in particular the Graf-Kuenen-Wellhausen Protestant school of biblical interpretation. ${ }^{54}$ This work speaks of a distinctive and more Orthodox, yet scientific attitude toward the study of the Bible that began to develop in that period, one which stirred much interest and conflict and became a full-fledged European scholarly practice. ${ }^{55}$ Cassuto moved to the Hebrew University in Jerusalem in 1939, where he worked primarily as a biblical scholar, his theory gaining some interest after his death. ${ }^{56}$

These were the formative years also of Arnaldo Momigliano, who started out as a scholar of classics, and although Momigliano chose a different field of expertise, he left a strong mark on all things Jewish. Arnaldo (1908-1987) was born into a family of Piedmontese Jews and received, according to his own words, a strict Orthodox Jewish education. ${ }^{57}$ Members of the Momigliano family were very active in the Italian cultural scene: a few deserve special attention, such as Arnaldo's uncle Felice, on

\footnotetext{
${ }^{52}$ Alberto Soggin, "Umberto Cassuto," Dizionario biografico degli Italiani, 21 (1978) (http://www.treccani.it/enciclopedia/umberto-cassuto_(Dizionario-Biografico)/).

${ }^{53}$ Umberto Cassuto, Gli ebrei di Firenze nell'età del Rinascimento (Florence: Galletti, 1918).

${ }^{54}$ Facchini, David Castelli. Castelli accepted, even if with some scepticism, Wellhausen's interpretation of the biblical material.

${ }^{55}$ Julius Wellhausen was probably one of the most influential biblical scholars of the modern age. His work has often been criticized by Jewish scholars. See Aly Elrefaei, Wellhausen and Kaufmann: Ancient Israel and its Religious History in the Works of Julius Wellhausen and Yehezkel Kaufmann (Berlin: De Gruyter, 2015); Anders Gerdmar, Roots of Theological Antisemitism: German Biblical Interpretation and the Jews, from Herder and Semler to Kittel and Bultmann (Leiden: Brill, 2009); Wiese, Challenging Colonial Discourse, 217ff. We should therefore take Cassuto's interpretation of the Bible as a conservative answer to Julius Wellhausen and its reception in Italy.

${ }^{56}$ See Myers, "Was there a 'Jerusalem School'?"

${ }^{57}$ Arnaldo Momigliano, Pagine ebraiche, revised 2nd edition (Rome: Ed. Storia e letteratura, 2016).
} 
whom we shall briefly focus later in this essay. Another is Attilio, a literary critic who taught at the University of Florence and was a vocal anti-Fascist from an early phase. ${ }^{58}$

The young Arnaldo Momigliano grew up in a family that supported the Fascist movement, and his formative years seem to suggest a full adherence to the ideological tenets of the regime. Indeed, in 1931, he was installed as a professor of ancient history at the University of Rome, after his beloved professor, Gaetano De Sanctis, refused to pledge an oath to the Fascist regime. ${ }^{59}$ Momigliano wrote about the Maccabees, Hellenism, and Hellenistic Judaism, and developed an interest in so-called apocalyptic literature and messianism. In general terms, these are all subjects that were being debated in the academic world, although Fascist Italy attempted to transmit a tone of nationalism imbued with Idealism into much of the discourse. ${ }^{60}$ As Tessa Rajak suggests, Momigliano sifted through Jewish themes and reflected upon their encounter with Christianity, which was a topical question in this period. ${ }^{61}$ Momigliano is recalled here for two main reasons: he is part of a broader Italian and transnational Wissenschaft des Judentums, and some of his interpretations reverberate through Italian historiography on Judaism and the Jews. ${ }^{62}$ His contribution to the history of scholarship, classics, and Judaism was immense, with his career taking a

${ }^{58}$ Enrico Ghidetti, Attilio Momigliano, in Dizionario biografico degli Italiani 75 (2011) (http://www.treccani.it/enciclopedia/attilio-momigliano_(Dizionario-Biografico)/).

${ }^{59}$ Carlo Dionisotti, Ricordi della scuola italiana (Rome: Ed. Storia e letteratura, 1998), $385 \mathrm{ff}$. For De Sanctis see: Giorgio Boatti, Preferirei di no. Le storie dei dodici professori che si opposero a Mussolini (Turin: Einaudi, 2001); Helmut Goetz, Il giuramento rifiutato. I docenti universitari e il regime fascista (Florence: La Nuova Italia, 2000).

${ }^{60}$ On this topic see Mario Mazza, "Attualismo, storicismo, modernismo. Adolfo Omodeo e la storia delle origini cristiane," in La storiografia storico-religiosa italiana tra la fine dell'800 e la seconda guerra mondiale, 45-77.

${ }^{61}$ Simon Levis Sullam insisted upon Momigliano's Jewish identity and offered an interesting portrait of the young Momigliano. See Simon Levis Sullam, "Arnaldo Momigliano e la nazionalizzazione parallela: autobiografia, religione, storia," Passato e presente 70 (2007): 59-82. On Momigliano as a scholar of Judaism, see Tessa Rajak, "Momigliano and Judaism," in The Legacy of Momigliano, eds. Charles Burnett and Jill Kraye (London and Turin: The Warburg Institute-Nino Aragno Editore, 2014), 89-106; a remarkable and insightful interpretation of Momigliano's scholarship is to be found in Peter Brown, "Arnaldo Dante Momigliano, 1908-1987," in Proceedings of the British Academy LXXIV (1988): 405-442.

${ }^{62}$ The review of Cecil Roth, The Jews of Venice (Philadelphia: Jewish Publication Society, 1930 ) which is usually mentioned in reference to the "parallel nationalization" is now in Momigliano, Pagine ebraiche. Momigliano reviewed the Italian translation of Roth's book which was published by Dante Lattes in 1933. 
dramatic turn after the implementation of Italy's racial laws. Moreover, his understanding of ancient Judaism and early Christianity may shed light on the cultural context under exploration, especially in reference to the rise of Christianity and its relationship with Judaism.

\section{The "Warzone" of the Historical Jesus: ENTANGLED REPRESENTATIONS}

The rise of the "historical Jesus" is a fascinating branch of Western modern scholarship, and it is usually rooted in the German cultural and theological context of the late eighteenth century. ${ }^{63}$ Beginning in the nineteenth century, hundreds of books on the historical Jesus were published in Germany, as a result of a combination of Lutheran theology and the preeminence of historical thought. German scholarship was sophisticated and refined. The study of the historical Jesus was conducted by scholars who were primarily theologians, and whose works were defined by the disciplinary configuration of German academia. But the Germans did not go unchallenged, as French and British scholars engaged in the same fascinating topic. In France, even before Ernest Renan's controversial bestseller Vie de Jésus was published in 1863, Joseph Salvador's La vie de Jésus Christ had been published in 1838, after David Strauss' influential and enormously renowned biography of Jesus, published in $1835 .{ }^{64}$ Members of the Wissenschaft des Judentums wrote also some very relevant portraits of the historical Jesus. The most important Jewish works on Jesus were written by Abraham Geiger and Heinrich Graetz, the latter's being a direct polemical answer to Ernest Renan's Vie de Jésus. ${ }^{65}$

${ }^{63}$ Albert Schweitzer, Geschichte der Jesu-Leben-Forschung (Stuttgart: UTB, 1984).

${ }^{64}$ David F. Strauss, Das Leben Jesu, kritisch bearbeitet, 2 vols. (Tubingen: Osiander, 1835-1836); Joseph Salvador, Jésus-Christ et sa doctrine. Histoire de la naissance de l'Église, de son organisation et de ses origines pendant le premier siècle, 2 vols. (Bruxelles: Société belge de Librarie Hauman et Compagnie, 1838); Francesca Sofia, "Gerusalemme tra Roma e Parigi. Joseph Salvador e le origini del cristianesimo," Annali di storia dell'esegesi 21/2 (2004): 645-62; Matthew B. Hoffman, From Rebel to Rabbi: Reclaiming Jesus and the Making of Modern Jewish Culture (Stanford: Stanford University Press, 2007).

${ }^{65}$ See Susannah Heschel, Abraham Geiger and the Jewish Jesus (Chicago: Chicago University Press, 1997); on Graetz and early Christianity, Michael Brenner, Prophets of the Past: Interpreters of Jewish History (Princeton: Princeton University Press, 2010), Chapter 2. The Essenes' hypothesis of the rise of Christianity was developed also by the Italian Elia Benamozegh. Some remarks on this topic in Cristiana Facchini, "The immortal traveler'. How historiography saved Judaism," Archiv für Religionsgeschichte (forthcoming 2018) and Facchini, David Castelli. 
The Italian context is still overlooked, but we may be able to detect the web of relationships and influences between scholars of different faiths, and the role the Wissenschaft des Judentums played in this particular field of research. At the onset of the twentieth century the debate over the "historical Jesus" became increasingly multi-religious. The entanglement of various scholarly, religious, and political commitments is apparent in an encounter that occurred in 1921-1922. That is when the journal Bilychnis, a Protestant periodical founded by an Italian Calvinist and, according to Arnaldo Momigliano, one of the most innovative venues for the study of religions, published a multi-faith collection of articles on Jesus, his relationship with Judaism, and the rise of Christianity. ${ }^{66}$ Elga Ohlsen invited intellectuals of different religious backgrounds, although ultimately only Protestants and Jews participated, to answer the following questions: "Which are the specific [ethical] values of Christianity and Judaism? What is the essence of the new Covenant in relation to the old Covenant? Where is the border between the two religious systems?" 67

The first article was written by Dante Lattes, an Italian rabbi trained at the Collegio rabbinico of Livorno, where he had been a pupil of Elia Benamozegh. Lattes spent some time in Trieste, becoming acquainted with the Jewish culture of Eastern Europe.$^{68}$ Lattes underlined a scholarly tradition that was embedded in the late nineteenth-century debate associated with the Italian-French intellectual milieu, where the Jewishness of Jesus and his ethical teachings were particularly emphasized. The Gospels were, according to this narrative, both influenced by the core message of the prophets and the ethics of rabbinic literature. The common enemyfor Jews and Christians alike-was "Paganism."

This position aimed to voice two main issues: the ethical message of biblical prophecy and the relevance of Jewish messianism, a theme that fueled many conflicting interpretations among the Jews who had analyzed it. ${ }^{69}$ Lattes, who was both Orthodox and close to Jewish socialism

${ }^{66} \mathrm{~A}$ preliminary remark on this debate in Alberto Cavaglion, "La linea cenobitica e le aporie dell'ebraismo laico," Rivista di storia e letteratura religiosa XLVIII/3 (2012): 625-634; Laura Demofonti, La riforma nell'Italia del primo Novecento: gruppi e riviste di ispirazione evangelica (Rome: Storia e letteratura, 2003); Facchini, "Orientalistica ed ebraismo."

${ }^{67}$ Facchini, "Orientalistica ed ebraismo."

${ }^{68}$ See Facchini, David Castelli.

${ }^{69}$ Facchini, David Castelli, Chapter 3. At the beginning of the twentieth century many notions of messianism circulated. 
(via Zionism from Eastern Europe), stressed that Jewish teachings retained a social dimension that was absent in the so-called "Aryan version" of Christianity. He highlighted that Judaism performed both a national and universal religious function, following in the footsteps of his teacher Benamozegh. Collective ethical instruction-like social justice, for example-also belonged to the teachings of Jesus, but they had somehow become obliterated by Christianity. ${ }^{70}$

The second Jewish voice came from Giorgio Levi Della Vida, whose position was the most academic and (allegedly) emotionally detached. He himself emphasized being konfessionlos. Although he never wrote about Jesus, he did write about ancient Judaism and Islam. What he stressed in this article is nevertheless interesting: he acknowledged that the "essence of Christianity"-that is, its unique features-lay in the originality of Jesus' religious experience (coscienza religiosa) or, in other words, in his highly individualized religious experience. That said, he then asked himself whether it was possible for the historian of religion to detect the real nature of that experience. And of course the answer was negative. Levi Della Vida's criticism was also addressed to his fellow Jews who attempted to reinterpret religious history-both Christian and Jewish-in order to infuse new life into their religious communities. He was particularly critical of "Neo-messianism" (as he labeled Zionism), as a new movement to reinvent Judaism in modern times. According to Levi Della Vida, Judaism had no universal call and would therefore not be able to reinstate one. According to him, the attempt to rejuvenate Judaism brought about by Zionism was paradoxically linked to the appropriation of Christianity's genetic relationship with Judaism, but the task would be to no avail. Levi Della Vida was quite sensitive on one point, namely that the similarities between the two religions were, in fact, the core cause of their conflict. The call for universal ethical values was mutually exclusive. In other words, Levi Della Vida detected what Freud described as the "narcissism of small differences," which was indeed a cause of deep conflict. ${ }^{71}$

\footnotetext{
${ }^{70}$ According to Lattes, the universal ethical dimension of Christianity was utopian.

${ }^{71}$ Giorgio Levi Della Vida, "Cristianesimo ed Ebraismo," Bilychnis 17 anno X (1921): 395-399. He repeats the same in his Fantasmi ritrovati. Freud's notion of "der Narzissmus der kleinen Differenzen" first appeared in Das Unbehagen in der Kultur (1930) and then in Der Mann Moses und die monotheistische Religion (1939). Sigmund Freud, "Civilization and its Discontents," in The Standard Edition of the Complete Psychological Works of Sigmund Freud, Vol. 21 (London: The Hogarth Press and the Institute of Psychoanalysis, 1962).
} 
The debate, which was symptomatic of the clash between Protestants and Jews over the interpretation of Jesus and Christianity, also included the opinion of Felice Momigliano, whose allegiances stood with Reform Judaism and Socialism. Momigliano represents the position of those Jews who, beginning in the nineteenth century, had been attracted by Christianity as an inspiring source to reshape Judaism, as a way to strengthen ties with Christians, and to push for Judaism to become a religion with a universal inclination. Momigliano had Some Elements in the Religious Teaching of Jesus (London: Macmillan, 1910), a book written by Claude Goldsmith Montefiore, the most outspoken representative of Liberal/Reform Judaism in Britain, translated into Italian in $1913 .{ }^{72}$

Indeed, by the first decade of the twentieth century research on Jesus and early Christianity in Italy could be accessed through pamphlets, commentaries, book reviews, and translations. When Montefiore's book appeared in Italian, there were two works of Baldassarre Labanca already available: Gesì Cristo nella letteratura contemporanea straniera e italiana: studio storico-scientifico (1903) and Gesì di "Nazareth" (1910), the latter published by the same press as Montefiore's. Adolfo Omodeo, the pupil of the powerful philosopher and Fascist Italy's Minister of Culture Giovanni Gentile, published Gesù e le origini del cristianesimo in 1913, and Luigi Salvatorelli, an intellectual and journalist who started his career as a historian of Christianity, published Il significato di "Nazareno" in 1911 and $\mathrm{Il}$ mito di Cristo in $1914 .^{73}$ By the late 1920s, Omodeo had published a body of work on early Christianity, which included Gesù (1923) and Gesì il Nazareno (1927).

The book series directed by the Jewish publisher Angelo Fortunato Formiggini was pivotal in giving considerable visibility to different interpretations of the life of Jesus. Alongside Labanca's and Montefiore's works, Formiggini published Buonaiuti's Gesì il Cristo in 1926. Formiggini, who committed suicide in 1938 after the implementation of the racial laws, was a strong critic of neo-Idealism. His publishing house created two book series-Profili (Profiles) and Apologie (Apologies)-

${ }^{72}$ Claude G. Montefiore, Gesì Cristo nel pensiero ebraico contemporaneo. Introduzione di Felice Momigliano (Genoa: A.F. Formiggini, 1913).

${ }^{73}$ Luigi Salvatorelli, Da Locke a Reitzenstein: l'indagine storica delle origini cristiane (Cosenza: L. Giordano, 1988); Gabriele Boccaccini, "Gesù ebreo e cristiano: sviluppi e prospettive di ricerca sul Gesù storico in Italia, dall'Ottocento ad oggi," Henoch, 29 (2007): 105-154; Samuele Nicoli, La cultura cattolica e gli studi religiosi in Italia fra Ottocento e Novecento (http://manfrediana2.racine.ra.it/files/lanzoni2011/nicoli.pdf). 
meant to provide a broad and diverse interpretation of the history of religions. In the series Apologie he published Buonaiuti's Apologia del cristianesimo (Apology of Christianity) and Rensi's Apologia dell'ateismo (Apology of Atheism).

Italian scholars brought the many debates that circulated in Europe to Italy, familiarizing their audience with the most important scholarship of the time, from von Harnack to Bousset, from Weiss to Loisy, and applying to the study of ancient Judaism the rising methodology and theories of Religionswissenschaftschule. ${ }^{74}$ What is usually overlooked is the Jewish component of this debate, which was the only counter-narrative to a historical Jesus who, even when acknowledged as Jewish and fully immersed in his Jewish environment, remained exceptionally unique as a "Jew." Whether it was von Harnack's extraordinary ethical personality, Bousset's apocalyptic preacher, or Loisy's eschatological figure, Jesus often transcended his Jewish background. ${ }^{75}$ Jewish scholarship provided a different, and often contested, interpretation of the Jewish Jesus.

It is against this background that the work of the youngest among the Polish Jews who arrived to Italy will be briefly analyzed here. It is not surprising that Israel Zoller published, in 1938, a strange and forgotten book on Jesus, under the title Il Nazareno. ${ }^{76}$ As mentioned above, Zoller was part of a scholarly community that was divided between religious leadership and research. The Polish-Germanized Italian milieu to which he belonged had brought to Italy scholars like Samuel Margulies, Ismar Elbogen, Hirsh Perez Chajes, and Isaiah Sonne, surveyed above. Chajes in particular was involved in reassessing the Jewish context of the Gospels, and quite interestingly, in identifying the Hebraic wording of the Gospel of Mark. ${ }^{77}$ Although this was a tradition that dated back to the Christian

\footnotetext{
${ }^{74}$ See Luca Arcari, "La comparazione come metodo di selezione 'cristianocentrica' in Wilhelm Bousset. La 'sostanziale differenza' del giudaismo nel comparativismo storico-religioso tra Ottocento e Novecento," in Non solo verso Oriente. Studi sull'ebraismo in onore di Pier Cesare Ioly Zorattini, eds. Maddalena Del Bianco Cotrozzi, Riccardo Di Segni and Marcello Massenzio (Florence: L.S. Olschki, 2014), 597-621.

${ }^{75} \mathrm{On}$ Jewish answers to this rhetorical and historical narrative see Wiese, Challenging Colonial Discourse. For a broader assessment of the conflict over the interpretation of Biblical religion, ancient Judaism, and early Christianity see Gerdmar, Roots of Theological Antisemitism.

${ }^{76}$ Israel Zoller, Il Nazareno. Studi di esegesi neotestamentaria alla luce dell'aramaico e del pensiero rabbinico (Udine: Istituto delle Edizioni Accademiche, 1938); it was published as Eugenio Zolli, Christus (Rome: AVE, 1946). Latorre, Il carteggio Zolli-Pettazzoni.

${ }^{77}$ Hirsch P. Chajes, Markus-Studien (Berlin: C. A. Schwetschke, 1899).
} 
Hebraists of the early modern period, it was usually the Gospel of Matthew that attracted that sort of investigation. Christian scholars had emphasized the significance of Jesus' words since the Renaissance, in order to precisely reconstruct his teachings. ${ }^{78}$ In 1925, Harry Wolfson, a historian of Jewish philosophy who taught at Harvard and was born in the Russian Empire, wrote: "Jesus will not be reclaimed as God, nor as a son of God, a Messiah, or a prophet, but as a Galilean preacher." 79 Wolfson wanted to repossess the "sayings of Jesus" as part of the literary treasury of the Jews. "Jesus' sayings," wrote Wolfson, "were to be conceived as part of the maxims of the anonymous body of the wise, who expressed the national genius of the people." 80 The un-heroic, un-saintly, above all too human Jesus of Wolfson's was not very different from the one Joseph Klausner sketched in his renowned book on Jesus in 1922. Klausner was a Lithuanian Jew, a committed Zionist who had moved to Palestine where he was to become one of the first professors of the Hebrew University. Klausner's description of Jesus was generally more positive, presenting him as a figure with a political messianic calling. His book was influential: printed in Modern Hebrew, it was soon translated into English, French, and German (with several reprints). ${ }^{81}$ It created resentment among Eastern European Jews, and the publication proved to be hazardous to him. He had to renounce his position as a historian of Judaism to devote himself exclusively to Hebrew literature, a much less contentious field. ${ }^{82}$

When Israel Zoller published a lengthy book on Jesus in 1938, under the title Il Nazareno (The Nazarene), he was well acquainted with a wide European intellectual debate over the historical Jesus. Zoller's Il nazareno is to be interpreted in reference to this new attention toward Jesus, but

\footnotetext{
${ }^{78}$ See Jonathan Z. Smith, Drudgery Divine: In the Comparison of Early Christianities and the Religions of Late Antiquity (Chicago: University of Chicago Press, 1994).

${ }^{79}$ Neta Stahl, Jesus among the Jews: Representation and Thought (London and New York: Routledge, 2012).

${ }^{80}$ Ibid., 4.

${ }^{81}$ Joseph Klausner, Jesus of Nazareth: His Life, Times \& Teaching (New York: Macmillan, 1925 ). It is worth mentioning that Klausner, who also was a Jew from Eastern Europe, published his Jesus in Hebrew. The English translation was made by a Christian Zionist, the Reverend Herbert Danby. Klausner's work reached international acclaim. On Klausner see Dan Jaffé, Jésus sous la plume des historiens juifs du xxe siècle. Approche historique, perspectives historiographiques, analyses méthodologiques (Paris: Cerf, 2009) and the autobiographical novel of Amos Oz, A Tale of Love and Darkness. Engl. Transl. (London: Chatto and Windus, 2004).

${ }^{82}$ See also Jaffé, Jésus sous la plume des historiens juifs.
} 
also within a European context where research on the historical Jesus was blossoming. Whilst Zoller had a thorough Italian education and strong ties with Ernesto Buonaiuti and Raffaele Pettazzoni, the dean of history of religions in Italy, he was linked to Jewish networks of scholars and particularly indebted to the work of Chajes and Elbogen who had been his teachers in Florence.

Il Nazareno seems to fit particularly well with the idea expressed by Wolfson, as it was mainly, albeit not exclusively, devoted to the analysis of certain sayings of Jesus. It also incorporates chapters that had appeared in previous years as separate articles, where Zoller engaged with the comparison between Jewish and Christian rituals. As in the case of Wolfson, Zoller's Jesus is a preacher, but also a teacher of wisdom. Zoller attempts to recover the Hebrew and Aramaic language of the Gospels, and, through the language, the mindset and the religious experience of the preacher. ${ }^{83}$ It is the oral dimension of Jesus' teachings that have to be restored to their plausible historical ultra-Jewish setting, Zoller argues. Zoller is probably one of the first to bring in literary evidence from a later period, drawn from liturgical or mystical texts. At times, his own religious experience guides his interpretation of certain words. As for the other articles included in Il Nazareno, a more phenomenological analysis of certain literary evidence is offered, combining textual exegesis with a sensitive reading of symbolical religious forms. ${ }^{84}$

A book on Jesus can be praised, become a scandal (with all its consequences), or be totally ignored. One could assume that there was probably no worse moment for a Jewish scholar to engage in the Italian cultural scene than in 1938, when the racial laws were being implemented. ${ }^{85}$ An emphatically Jewish Jesus in 1938 Italy must be interpreted against the atmosphere of the anti-Semitic campaign launched by the regime in 1937, when biblical scholars like Father Giuseppe Ricciotti became fully involved with the crusade against Jews. ${ }^{86}$ But surprisingly, whereas Pietro

\footnotetext{
${ }^{83}$ Exactly what Levi Della Vida thought is impossible to recover through a historical analysis.

${ }^{84}$ Zoller, Il Nazareno.

${ }^{85}$ Sarfatti, Gli ebrei nell'Italia fascista. On Italian anti-Semitism and Catholics see Giovanni Miccoli, Antisemitismo e cattolicesimo (Brescia: Morcelliana, 2013); Elena Mazzini, Ostilità convergenti. Stampa diocesana, razzismo e antisemitismo nell'Italia fascista (1937-1939) (Naples: Edizioni Scientifiche Italiane, 2013).

${ }^{86}$ Giuseppe Ricciotti, Vita di Gesù (Rome: Rizzoli, 1941). On Ricciotti's anti-Semitic articles see Cristiana Facchini, "Culture cattoliche ed ebrei dopo la Shoah. Riflessioni a mar-
} 
Martinetti's Gesù Cristo e il cristianesimo-published in 1934-was put on the Index of Prohibited Books of the Catholic Church, Zoller's book went almost unnoticed. The only positive review of Zoller's work was written by Ernesto Buonaiuti, who had once published some of Zoller's articles, and who had been persecuted both by the Fascist regime and the Catholic Church. ${ }^{87}$

Zoller managed to remain in Italy even after 1937, possibly with the help of Raffaele Pettazzoni. ${ }^{88}$ In 1944, while observing the Yom Kippur fast, he had a vision of the Holy Virgin, and in 1945 converted to Catholicism. After the war his book was reprinted under the title Christus. He was banned by the Jewish community and treated as a traitor, an apostate who had abandoned his people in its darkest hour. Among the Catholics he found the peaceful atmosphere he had been seeking, although he remained a marginal scholar, being-in my interpretation-too Jewish to be relevant.

\section{Transnational Intellectuals and the Human Condition of Exile}

This chapter has described trajectories and works of scholars who belonged to the wider network of the Wissenschaft des Judentums in the first decades of the twentieth century and some of their entanglements with non-Jewish scholars. Although the rise of Fascism brought about a new ideological frame, influenced by neo-Idealism and by the increasing role of the Catholic Church, research on religious topics remained both an important field of research and a source of distress. It is remarkable that, despite the incredible amount of censorship and control exerted both by the Church and the Fascist regime, research on religion and the scholarly study of Judaism and Christianity flourished in a country with low literacy, where the Bible was not at the center of community life.

The Wissenschaft des Judentums comprises a diverse set of topics, some of which I briefly described here, and some of which remain in the background. The most significant, yet controversial, dealt with the Bible and

gine di due recenti pubblicazioni," Annali di storia dell'esegesi 29/1 (2012): 149-173. His articles were published in L'avvenire d'Italia, a Catholic daily newspaper based in Bologna.

${ }^{87}$ Ernesto Buonaiuti in Religio. Latorre, Il carteggio Zolli-Pettazzoni.

${ }^{88}$ See Michael Stausberg, "Raffaele Pettazzoni," in The Study of Religion Under the Impact of Fascism, ed. Horst Junginger (Leiden and Boston: Brill, 2008), 365-395. 
its interpretation, which entailed examining the notion of the religion of ancient Israel and the rise of Christianity. This topic became a battlefield, especially for those who lived in Catholic countries and who did not receive enough protection from state institutions. The study of the Bible was also transnational, as it affected scholars in different countries and with diverse religious upbringings. The Jewish contribution to this field in Italy was probably very significant, as in other countries, like in Germany, where Jews largely opposed the master narratives of the powerful theologians and academics of their time. The entangled history approach I described in this article helps to better visualize the transnational character of scholarship, and its relationship with the different types of local culture. Although Fascism aimed to impress a strong national character upon anything Italian, when it came to the study of religions it was unable to control the output of different scholarly traditions. Moreover, despite the desire to imprint everything with a national stamp, scholarship was-until the impact of Nazism on certain areas of research - relatively transnational, in the sense that groundbreaking studies could not be ignored, even when contested. Despite the relative openness of scholarly borders, however, it is worth emphasizing the harshness of this historical period and the impact of the discrimination that affected all of these authors. The Wissenschaft des Judentums may then provide an interesting background for the study of religious themes, which go beyond the mere question of Jewish identity, but address general questions of intellectual history in times of persecution, where exile becomes a shared condition of existence. 